\title{
Reading without habits: a Caribbean contribution to World Literature
}

A curious "cosmopolitan moment" took place during the European maritime expansion that brought us the colonization of the Americas and the Middle Passage. Paul Gilroy notes in The Black Atlantic that ships brought not only slaves to the Caribbean, but also subversive books. The circulation of books outside their context of origin - which is, in a nutshell, World Literature's object of study - played an essential role in shaping knowledge and politics in the New World, contributing to the region's distinctive cultural hybridity, as well as forming the basis of its social resistance. ${ }^{1}$ In this essay, I discuss cosmopolitan reading in five Caribbean novels: Alejo Carpentier's Explosion in a Cathedral (1962), Leonardo Padura's La neblina del ayer (2005) and Herejes (2013), Marlon James' The Book of Night Women (2009), and Mayra Montero's In the Palm of Darkness (1995). I focus on "bad" reading (interrupted reading, misreading, nonreading) as a way to interrogate how the operation of imagining the other results in opacity rather than insight. I ultimately explore what this means in terms of both Caribbean culture and the paradigm we call World Literature.

Reconciling two different yet complementary notions - Mariano Siskind's "desire for the world", and Ulrich Beck's "global risk society" - I suggest that we read literature produced in cultures and languages other than our own in part because it articulates urges, desires, and concerns that we share, but that our own imagination and creative processes may have not yet captured. In Cosmopolitan Desires, Siskind coins the phrase "a desire for the world" to name the elusive aspiration of Latin American writers to attain both modernity and universality. Siskind defines the world as a "necessary fantasy" that mediates both ethically and aesthetically between the marginality of the Latin American writer and an imagined universal literary community. Siskind's book also discusses key aesthetic moments in Latin American letters in which this "desire for the world" becomes more palpable, such as modernismo and magical realism. In turn, Ulrich Beck's "world risk society" discusses "cosmopolitan moments" in which a shared anticipation of catastrophe, either real or perceived, steers human beings to "lend meaning to their lives through exchanges with

1 For a detailed discussion on the theory of World Literature and Latin America, see De Ferrari (2012).

¿ Open Access. (C) 2019 Guillermina De Ferrari, published by De Gruyter. (cc) BY-NC-ND This work is licensed under a Creative Commons Attribution-NonCommercial-NoDerivatives 4.0 License.

https://doi.org/10.1515/9783110641134-012 
others and no longer in encounters with people like themselves” (Beck 2009: 15). By combining the complementary notions of desire of the world (Siskind) and global risk (Beck), I want to shift the emphasis from geography to history, for I believe that we are citizens of our times more than citizens of our nations. In my discussion, I hope to show that an important reason we read across languages and borders is to make sense of the uncertainties posed by impending change, to perceive and interpret shared risks, and to imagine opportunities of survival together with a community of strangers.

I analyze here five novels that correspond to three "cosmopolitan moments": the end of the divine right of kings and the birth of the modern state in the French Revolution; the fall of the Soviet bloc and a variation on what Francis Fukuyama calls “the end of history"; and Bill McKibben's "the end of nature" to refer to the stage of the Anthropocene in which we live today. With these moments in mind, I examine how books, ideas and even revolutions travel from their place of origin into the Caribbean and help shape knowledge in the postcolonial world. I suggest that misunderstanding and misappropriation, which are constitutive aspects of Caribbean modernity, are also inherent in World Literature. This is no accident: the DNA of the modern Caribbean is cosmopolitan. I will analyze Caribbean literature to explore the counterintuitive argument that imperfect reading is a productive aspect of the World Literature paradigm.

To state the obvious, World Literature, a human activity, cannot be extricated from other social relations. Therefore, reading badly is not necessarily programmatic, but rather a symptom and an extension of our complex human entanglements. Members of the human community are imbricated with one another as well as with place and history in a way that justifies an aesthetic, intellectual, and affective dialogue that is, I suggest, only fully possible when embracing its ahistorical imperfection. This is not to say that humans always manage to understand one another across linguistic and cultural barriers. World Literature engages ambiguously and fallibly with the opacity of the other, to use Édouard Glissant's term (Glissant 1997: 190), often using the other as a scene of projection (see Aching 2012).

This essay engages with World Literature as a form of reading otherwise, by which I mean reading with the awareness that reading the other produces compromised knowledge. I focus on different instances of the transplanted book in an arbitrary array of Caribbean novels to suggest that reading well, or even reading at all, is not required for literature to travel - not even for it to travel “well”. Rather, I argue, what matters most is why a reader reaches out for specific books, suggesting perhaps that certain times call for certain stories. Ultimately, I suggest that the individual quest for (dislocated) meaning leads to 
a consistent, almost predictable form of misreading. I borrow a term from ecocriticism to ultimately suggest that World Literature misreads the specific while it works, and often works best, at the level of the species.

\section{Alejo Carpentier's unpacked boxes}

Because some novels anticipate theory, I see Carpentier's 1962 novel El siglo de las luces as a ship in a bottle; that is, a scale model to understand the practices and processes that one may call Caribbean World Literature. The novel is about revolution and disenchantment. Whereas the idea of the French Revolution is strategically staged in the novel through the death of the tyrant father - an absolutist king figure -, the historical French Revolution is at first concealed in plain sight, as the news in a Cuban newspaper is smaller than a guitar store advertisement. Revolutionary passion and disenchantment steer Carpentier's El siglo de las luces, a bildungsroman that follows two Cuban characters from youth to maturity in the last decade of the eighteenth century and the first decade of the nineteenth-century. As the characters mature politically and philosophically, they travel from Havana to Port-au-Prince to Paris, then to Guadeloupe and Cayenne, back to Havana, and finally to Madrid. Set during the age of Enlightenment, or "el siglo de las luces", as it is known in Spanish, the novel marvels at scientific progress, revolutionary ideas, and new philosophies. I will briefly focus on three interconnected instances of cultural travel: cultural artefacts (in the form of scientific instruments and books), the act of mis/reading, and translation.

El siglo de las luces begins with the death of the father, a wealthy merchant in eighteenth century Cuba. ${ }^{2}$ His death brings liberation to Esteban, Sofia, and Carlos, the three adolescents in the house, who close their Havana home to acquaintances and strangers and embrace a life of creative chaos. They order fancy products from overseas, including a very sophisticated physics set and a harp, which they never completely unpack. ${ }^{3}$ The partially opened boxes are stacked in various piles that create new topographies (prairies, mountains) which the children climb and where they lounge as they read natural history books, Greek tragedy, and science fiction novels. The boxes contain scientific

2 This reading of El siglo de las luces is partly based on my article "Las palabras y las cosas" (De Ferrari 2005).

3 The physics set includes "telescopios, balanzas hidrostáticas, trozos de ámbar, brújulas, imanes, tornillos de Arquímedes, modelos de cabrias, tubos comunicantes [etc.]" (Carpentier 2001 [1962]: 29). 
and musical instruments that remain disassembled and unused, like a closed box containing the harp that produces occasional musical notes when a string breaks due to the tropical heat. The few that have been unpacked are ostensibly misused: the hydrostatic scale weighs the cats, and a telescope helps them spy on neighbors. These objects fail to serve the purpose they were built for - that is, until the arrival of Victor Hugues, a French merchant and franc mason baker who will later become the Robespierre of the colonies. Hugues joins the adolescents in their games and eventually brings order to the house by unpacking and assembling the objects. ${ }^{4}$ The novel offers an implicit theory of how objects and knowledge travel: the kids desire the instruments for what they do, but the objects cannot perform their original functions until the French man supplies context, technical knowledge, and discipline. At the same time, however, the children's appropriation is partly creative. The children's use of these instruments of knowledge remains outside the objects' original economies.

Their creative neglect of the objects' purposes is further illuminated by way of contrast with the guillotine. The guillotine travels from France to Guadeloupe along with the printing press and copies of the decree of abolition. The guillotine comes in a box but is promptly assembled by carpenters and placed on the deck of the ship, where it is covered to protect it from the salty air. Carpentier's guillotine is both instrument and symbol - the novel even compares it to a theorem - and yet is destined to lose its conceptual purity in the tropics. When, following a few months of "proper" use, the guillotine is taken on the road in Guadeloupe, it is used not to chop off dissenting heads, but to cut sugar cane or a hand of bananas for the amusement of locals. So, when objects are used by Europeans, they are put to work properly (by this I don't mean put to a "good" or a "bad" use, but to a correct one). However, when used by locals, the objects quickly slide out of their semantic field and become generic tools that can be used for a variety of purposes: the guillotine becomes a powerful cutting machine.

While in France, Esteban is charged with the translation of French documents such as Les Droits de l'homme et du citoyen, as well as speeches and propaganda into Spanish. As he ardently believes in the importance of that political moment, he is both a cultural agent and an activist. At first, he is sincerely devoted to the mission of bringing the Revolution to Spain, but as he sees the terror that ensues in France, his work is reduced to mere professional

4 I would like to note the contrast here between the foreign instruments that are technically unused and useless as they are, and the ultramarinos shop they own and is housed on the other side of the wall, which sells useful things. 
zeal. He just likes to find the right word with no regard to the translation's ultimate purpose. His mission has become an aesthetic, not an ideological, one. However, his translations travel across the ocean and move the excited minds of the young - like Carlos, now a bourgeois revolutionary, and Sofía who, eight years later, feeds Esteban his own translations in her efforts to convert him to the revolutionary cause. This is destined to fail. The problem is that Esteban, now at the receiving end of his own words, knows too much to take them at face value. So, while the novel illustrates Esteban's disenchantment with revolutionary process (a reading that has led Carpentier to swear that the 1962 novel was written before the Cuban Revolution, to avoid unwelcome analogies), it also suggests that reading may be more productive when encountered from a certain position of ignorance.

If reading is reading oneself, even one's old reading is technically a misreading. Young Esteban passionately read and profusely marked Rousseau's The Social Contract in his adolescence, leaving marginalia in 1790 that becomes evidence against him in 1800 when he is arrested in colonial Cuba for his revolutionary ideas. Esteban no longer believes in the Revolution at that time, but that doesn't prevent the Spanish authorities from sending him to a prison in Ceuta where he spends the next seven years. The epilogue places Esteban and his cousin Sofía in Madrid during the Napoleonic invasion of 1808, where they join the resistance and disappear without a trace. We find out that after Ceuta, Esteban had only been interested in romantic literature (a sign of a deep change in the times and in his spirit). The material trace of his reading appears in a book, Chateaubriand's Le Genie du Christianisme, in the wrong place. The presence of this book, his book with his marginalia, in Sofia's bedroom, suggest that Sofía and Esteban were lovers. It is interesting that whereas an enlightened text creates a false reality, an anti-enlightenment and protoRomantic text offers a glimpse at the truth. The physical traces of reading can as easily provide a deceitful confession as a truthful one. Similarly, Sofía who has technically misread the French Revolution, stays true to the larger - one may say generic - concept of revolution; for it is Sofía who moves Esteban into action, any action, because doing nothing is not an option.

The difference between Esteban and Sofia's political reading lies in the inside knowledge that Esteban has (and that Sofía lacks). While Sofía reads the lines, Esteban reads between the lines. Or, to put it differently, Esteban understands the "metarules" of the French Revolution.

In Virtue and Terror, Slavoj Žižek explains the French Revolution's hidden rules, and the new habits that determine what kinds of behavior constitute appropriate responses: 
Every legal order [...] has to rely on a complex reflexive network of informal rules which tells us how are we to relate to the explicit norms, how are we to apply them: to what extent are we to take them literally, how and when are we allowed, solicited even, to disregard them, etc. - and this is the domain of habit. To know a society is to know the metarules of how to apply its explicit norms: when to use them or not use them; when to violate them; when not to use a choice which is offered; when we are effectively obliged to do something, but have to pretend that we are doing it as a free choice. (Žižek 2007: xviii)

And pondering about those "choices that are offered to us on condition that we make the right choice", Žižek offers a theory of greatness: "Measured against this background, revolutionary-egalitarian figures from Robespierre to John Brown are (potentially, at least) figures without habits: they refuse to take into account the habits that qualify the functioning of a universal rule" (Žižek 2007: xix; emphasis in the original).

Esteban is a disenchanted reader on account of his in situ experience. When he reads the revolutionary essays, ideas and manifestos, he knows when to read between the lines, what not to take literally, and what to ignore. He has acquired the habits of the revolutionary order of things. These metarules are not immediately available to a decontextualized reader like Sofía. What Esteban's knowledge of the metarules does for his reading of philosophical texts is similar to what Victor Hugues' knowledge of how the mechanisms of the instruments in the boxes work, and of the adulterated books in the family business, enables him to do. Victor Hugues' experience as a store owner allows him to see what was hidden between the lines, and save the children from being robbed by their legal guardian. However, as a statesman Hugues refuses to obey orders from France once the Revolution reverses course. It is his selective neglect of the metarules what makes him the Robespierre of the Caribbean.

The biggest unpacked box in Carpentier's novel is the Haitian Revolution. The Haitian Revolution - "an extension of the European revolution" 5 - is in no small part the result of a literal reading of Les Droits de l'homme et du citoyen,

5 Susan Buck-Morss (2009: 37). Buck-Morss' essay also traces the story of a misreading. BuckMorss wrote it as she wondered why Hegel would bring up the slave and the master in a conversation about civil society in Europe. Buck-Morss suggests that the origin of Hegel's master and slave dialectic may have originated not out of his dialogue with other European philosophers but out of the fact that Haiti was front-page news on a daily basis. The essay even proves that, until Buck-Morss pointed this out, Europeans were productively misreading Hegel. What is at stake in the proper contextualization of Hegel in relation to Haiti, states Buck-Morss, is "the recognition of freedom as a human" or, rather, universal "aspiration" (2009: 75). 
the key text that Esteban translates into Spanish in Carpentier's novel. Susan Buck-Morss suggests that

For almost a decade, before the violent elimination of whites signaled their deliberate retreat from universalist principles, the black Jacobins of Saint-Domingue surpassed the metropole in actively realizing the Enlightenment goal of human liberty, seeming to give proof that the French Revolution was not simply a European phenomenon but worldhistorical in its implications. (Buck-Morss 2009: 39)

One could say that it was ignorance of the metarules - not understanding that the proposed equality was meant to be limited to white French men -, that facilitates a literal, perhaps incomplete, yet liberating reading of the French Revolution. This is essential to an understanding of the (disavowed) Caribbean modernity that largely stems from the inherent contradictions between the socalled universal project of the enlightenment and the particulars of a race that had to negotiate their humanity in every sphere of life, contradictions that were not immediately recognized in the Saint Domingue of eighteenth century. ${ }^{6}$

The unopened boxes function as a microcosm of Caribbean modernity, in which texts, concepts and Revolutions are often unpacked only partially and with unexpected semantic malleability. By reflecting on the way instruments and concepts travel and behave in the Caribbean at the onset of European modernity, Carpentier's novel proposes a theory of a cosmopolitan periphery. The novel's extensive travel and engagement with European political philosophy reveals a deeply Caribbean "desire for the world". Such cosmopolitanism is best illustrated by Carpentier's two aesthetic projects: marvelous realism Carpentier's name for what he understands is the Caribbean's inherent surrealism - and the Neo-Baroque. The Neo-Baroque, defined by Severo Sarduy as a combination of excess, proliferation, and semantic displacements, is itself a misappropriation of a European aesthetics taken out of context. This is partly how Carpentier's novel helps advance an analogy between Caribbean culture and World Literature since, I suggest, a certain degree of misunderstanding makes World Literature not only possible but also desirable.

6 See Sibylle Fischer's Modernity Disavowed: Haiti and the Cultures of Slavery in the Age of Revolution. 


\section{Marlon James's impolite book}

Books are read in Marlon James's The Book of Night Women, and the reader is a slave girl named Lilith. She is a secret reader: nobody knows she can read, and she must hide while reading. She is what Henry Louis Gates Jr. calls "an impolite learner": her reading is not part of a deliberate effort to shape her character, but rather helps make evident the inhumane fiction that inequality was part of a "'natural' order of things" (Gates 1988: 52). Stealing time from sleep, she hides to devour Henry Fielding's Joseph Andrews. The risk and the importance of reading for Lilith is hard to put into words. If found, she might be physically punished by people who would not only disapprove of the entitlement behind the practice, but will also assume she is unable to understand the complexities of "civilized" - that is, British - novels and characters. However, punishment is what has put her in front of Fielding's book in the first place.

Lilith finds Fielding's novel when cleaning the library at Coulibre, the plantation where she has been sent for "training" after she accidentally splashed a guest's chaperone with scalding soup during a dinner party. ${ }^{7}$ The ghost of the Haitian Revolution looms over Jamaica, and the master's fear requires harsh discipline. Exile at Coulibre is the last one in a series of cruel punishments following the soup incident: Lilith was first hit in the face and body, then gang raped, then whipped, and finally taken to the new plantation to learn proper slave manners - or, in other words, to learn to show obedience in the face of any degree of injustice. In her new temporary home, Lilith befriends Dulcimena, who works in the kitchen slave and is the master's reluctant concubine, who has proven to have a sunny spirit even while enduring unspeakable tragedies. It is soon after the mistress of the house tortures and kills Dulcimena out of jealousy that Lilith finds Joseph Andrews in the library.

Her act of reading is illuminated by Henry Louis Gates' essay "James Gronnoiosaw and the Trope of the Talking Book", which suggests that participation in literary culture became the only way "to demonstrate individual membership in the human community" in the plantation context (Gates 1988: 52). Reading Fielding's novel gives Lilith a glimpse of what humanity not bound by the plantation's inhumane rules would be like. She sees the protagonist as a charming man: "There be only one man, one soul, that can make her laugh and he be neither black nor real" (James 2009: 206). It is of course paradoxical that only a fictional human being makes the slave girl feel human. Reading has

7 I should clarify that Lilith recognizes the book. She was already acquainted with before Coulibre. 
allowed her to create an imaginary society of equals. Such is the humanizing quality of literature: in the interaction between herself and a fictional human being, she sees herself as truly human. It is a devotion akin to love, "She need him every night. After working through a page, she would wipe away tears from laughing quiet-like and feel her face. The soft skin would surprise her" (James 2009: 207). Lilith becomes aware of her skin not in terms of color (with its assigned social and legal implications), but as the site of potential tenderness, of feeling loved. The book "talks" to her, draws her in, makes her feel like a person. In forgetting her life through reading, she is more her own self than ever.

However, the reality of the plantation interrupts. The more she is whipped, or sees others being whipped, the less comfort she finds in the book. Dignity and equality dissipate, giving way to a feeling of personal betrayal: "Joseph Andrews lying to her, making her wish for a place and time that never going' come". She holds the protagonist Joseph Andrews personally accountable: he is lying to her. Fully claiming her racialized self, she becomes aware of being not just a reader, but a deceived reader. She bitterly concludes "Nothing in this book a nigger can use"8 (James 2009: 220). Lilith has become a disenchanted reader not just of Fielding's novel, but of the indifference of the great European novel to the scandal of slavery. Fielding's has become an impolite book that fails to include her.

The novel is a creative medium that facilitates the imagining of lives other than our own. As such it requires, in principle, that the reader forgets herself. However, Lilith, who reads to forget her reality and attend to her soul, has become aware of the awareness of her own erasure. Acting as a distorted mirror, literature had shown her infinite possibilities. She had believed herself to be in full possession of her human attributes. By contrast, reality has taught her the dehumanizing dimension of her oppression. Lilith has understood the existence of the hidden rules of social interaction and assumptions - the "metarules" in the novel. As in the case of Esteban, it is reading well that makes her stop.

\section{Leonardo Padura's closed books}

Leonardo Padura is by far the most widely read living Cuban author. His novels, which have been translated to more than a dozen languages, often talk

8 Henry Louis Gates, Jr. bases his essay on resistance in antislavery literature on the resistance of the indigenous population via Guaman Poma's "paños que hablan”. 
about books. Those books are sought, bought and sold, and often worshipped, but they are rarely read or even opened. Padura's recurrent protagonist Mario Conde, a policeman and frustrated writer in the first four novels of the series Las cuatro estaciones, leaves the force and becomes a second-hand bookseller and a private detective in a place with, technically, no private sector.

In La neblina del ayer, Conde finds a gem of a library in the once-elegant El Vedado neighborhood. In it, he finds bibliographic treasures that have remained untouched for forty years, including nineteenth-century Cuban editions of European classics, like a first Cuban edition of Voltaire's Candide. He also finds "inconceivable delicacies of creole bibliography that he was seeing and touching for the first time"9 (Padura 2005: 67-68). He finds a natural history book by Ramón de la Sagra that includes 158 hand-colored engravings among many other books that look and feel very expensive. The price of each of these books is around ten thousand American dollars: if only one were to be sold, that sum would allow the library's owners and Conde to support themselves for years. However, as he goes through the shelves, Conde puts the most valuable Cuban books - "Aquellas delicatessen" (Padura 2005: 76) - in the unsellable pile: only foreigners can pay that amount of money, but Padura is adamant that national treasures should remain on the island. In his search for sellable yet valuable books, he finds a cookbook and in it a forty-year old newspaper clipping about the suspicious suicide of a bolero singer whose mysterious death will structure the detective part of the story. Convinced at heart that these treasures will end up being sold to undeserving foreigners, and because Conde's friends are his true treasures, Conde ends up stealing some of the unsellable books to give to his friends and even saves the first edition of José María Heredia's poem Niagara, published in Toluca in 1832, for his girlfriend. Heredia's book alone is worth about twelve thousand dollars but, in Conde's rationalization, taking these books to his friends is justice, not robbery (Padura 2005: 353).

In Padura's Neblina, this fantastic inventory of books makes up an idealized library at the very tip of Conde's fingers. Conde wallows in the luxury of naming and enumerating them. Curiously, the books are listed in terms of value (no value, collectible value, too much value, sentimental value, national value), but are not read. They are not "unpacked". More often than not, they are quickly recirculated and turned into food. Indeed, as soon as Conde gives the owners some money to ensure their exclusivity, they run to the black market to buy any form of protein. In turn, Conde's profit from his book-selling business is given to

9 Originally: "inconcebibles exquisiteces de la bibliografia criolla que veía y tocaba por primera vez". 
Josefina, a mother figure, who then procures all the ingredients to produce the most delicious traditional Cuban dishes. Finding all the ingredients is practically inconceivable, and Josefina makes "verdaderas exquisiteces de la cocina criolla" (Padura 2005: 67-68). Padura has stated that Josefina's cooking responds mostly to a fantasy because at the height of the Special Period, literature was the only way to make food happen. ${ }^{10}$ However, in contrast with the bibliographic delicacies that are named but not opened, Josefina's dishes are described in the minutest detail. Readers are not offered sensorial access to the food, but they do find in Josefina's retelling of the recipe a meticulous reconstruction of the dishes that amounts to a material presence. More than in the books, Padura wallows in the food. Fantastic cuisine, not a treasured library, ends up being a more efficient reservoir of nationalistic nostalgia.

In the novel Herejes, Padura tracks in part the disappearances of a European painting during WWII and of a teenage girl in the 2000s. The painting, a Rembrandt that was given by the painter to his Jewish apprentice, is in the hands of the apprentice's descendant on board the transatlantic liner St. Louis. The St. Louis sailed from Hamburg to Havana in 1939, carrying 937 passengers, most of whom were Jews fleeing Nazi Germany. The passengers held entry permits to Cuba that were not honored; they were not allowed to disembark, and after several days were sent back to Germany. In the novel, the owners of the Rembrandt on the ship give the painting to a Cuban immigration officer in exchange for an entry visa for their daughter, but they are robbed of the painting and of their last hope. The Rembrandt, stolen by a corrupt immigration official in 1939, is exported illegally in the 2000s by another corrupt official. While in Cuba, the illegally imported painting remains hidden (another "unpacked" box ${ }^{11}$ ) and trapped in corrupt, clandestine commercial transactions. It also stands for the inhumane act of not saving a Jewish girl named Judith from her death.

In the 2000s, before her disappearance, a 17-year old girl named Judy is profoundly disenchanted with the society she lives in. She is an Emo, part of the urban tribes in today's Havana, who imitate manga characters in clothing and hairstyle. They embrace a tragic ethos, making suicide a possible cause for her disappearance. Conde eventually finds Judy's murderer. While looking for clues, Conde finds three objects in the girl's room that obsess him: J.D. Salinger's The Catcher in the Rye, Nietzsche's Thus Spoke Zarathustra, and a DVD version of the 1982 film "Bladerunner". Conde

10 Stated during the book presentation of Adiós, Hemingway at Unión Nacional de Escritores y Artistas de Cuba in July 2001.

11 Perhaps it is hidden in plain sight, on a wall covered with reproductions. 
remembers the film very well and it even inspires him to solve the mystery in a dream, although his epiphany is eventually proven scientifically. He also remembers Salinger's coming-of-age novel, and his fond memories of having read it in his youth help Conde connect to Judy's own turbulent adolescence. The mention of Salinger helps create bibliographic empathy: Conde and most of us were Judy at some point in our lives. At the same time, however, Nietzsche's book persistently bothers Conde. It is true that Judy speaks through her readings, but what upsets Conde is Nietzsche himself, his godlessness, his lack of faith in the value of virtues and in human kind.

Conde's contact with Nietzsche's book starts with a handwritten note that falls out of its pages. It was written by Judy herself and, although it is not clear whether it is a direct quote of Zarathustra, it nonetheless reveals Judy's Nietzschean (godless) thoughts. When Conde explicitly tries to read the book, he finds it unpalatable, indigestible: "Mientras a duras penas deglutía a Nietzsche" (Padura 2013: 423), as he was trying to swallow Nietzsche's book with much difficulty, his mind turned to a list of people who could explain Emo philosophy and Judy's "mental confusion" to him. In other words, he looks for people who will help him not read Nietzsche. To this end, Conde goes to a former classmate, then to a teacher, then to a sociologist who is doing research on urban tribes. The latter helps him understand Judy's dark behavior in terms of the desire to liberate her mind from inherited ideas and from a system that is oppressive (Padura 2013: 373). The scholar has read David Le Breton extensively, and summarizes his ideas for Conde - that is, the scholar pre-digests the book for Conde. Le Breton, like Nietzsche, remains unread.

In contrast, Judy's literature teacher has kept one of her term papers, in which the girl quotes and comments on a passage in Carpentier's El siglo de las luces. It is a section in which Esteban complains of being trapped in Guadeloupe because of the war between France and England. Feeling as much a guest as a prisoner, Esteban elaborates on the bureaucratic difficulties of crossing borders:

passports, papers, stamped, signed and countersigned papers [...] permit, safe-conduct, passport, and any word that would indicate the authorization to a human being to allow him to travel from place to place [...] For fear of the Revolution as well as fear of the counter Revolution, the government and the police had put a limit to the ancestral freedom of man to move around the planet without having to subject his ancestral nomadism and sovereign will to move to a piece of a paper. ${ }^{12}$ (Padura 2013: 401-402)

12 Originally: "universal proliferación de papeles, cubiertos de cuños, sellos, firmas y contrafirmas, cuyos nombres agotaban los sinónimos de permiso, salvoconducto, pasaporte 
With this reference to borders and bureaucracy, Esteban describes the birth of the modern state. The quote seems to affect Judy in part because of her lack of freedom in a country where Cubans were required to obtain an exit visa in order to travel, testing citizens' loyalty to the regime. Judy is therefore complaining about one of the principles of the Socialist social contract in place in Cuba since 1959. More indirectly, in the novel this passage seems to allude to the story of the little Jewish girl named Judith who was denied an entry visa that would have saved her, although Judy the Emo has no apparent connection with her. The quote from Carpentier in Judy's paper ends with the idea that travel should not be forbidden because "la fidelidad por obligación es un fracaso" (Padura 2013: 401-402).

Minimal reading via a third party offers a theory of World Literature. Judy, the reader in this novel, is in fact dead. However, she leaves the material trace of having read books, but she has shed the particulars and embraced their spirit instead. Books help construct Judy's character and her defining disenchantment. ${ }^{13}$ It is no doubt ironic that the section devoted to the Emo girl Judy and the mystery of her death is called "The book of Judith". The biblical effect of the title is so ambiguous as to give the appearance of being named after the wrong girl. In her reading of the novel, Vicky Unruh suggests that Herejes is the first of Padura's novels dedicated to the future as opposed to his nostalgic musings. I would speculate that it is a future where books are little more than sterile physical props. ${ }^{14}$

There is a well-known precedent: in Guillermo Cabrera Infante's Tres tristes tigres, one of the protagonists, Silvestre, and his brother famously sell books from their father's library to fund their frequent trips to the movies. Similarly, Conde's displacement from reading to eating is not a surprising twist in postSoviet Cuba, where eating, especially eating well, is a complex and difficult operation. However, considering Mario Conde's stated obsession with books, the displacement from reading to food can be seen as a form of getting away with not unpacking the boxes. This suggests a critical paradigm of World Literature as "knowing" without "reading". Padura uncomfortably appeals to Nietzsche in a (late) Socialist appropriation of "the end of history". Francis Fukuyama wrote The End of History and the Last Man (1992) to reflect on the post-Soviet

\footnotetext{
y cuantos vocablos pudiesen siginificar una autorización para moverse de un país a otro... tuviese que someter su soberana voluntad de traslado a un papel”.

13 Padura is borrowing Carpentier to address a historical process that either resembles the Cuban Revolution (similarity and repetition) or one in which he himself is somehow still inserted (continuity).
}

14 Part of this reading appears in De Ferrari/Unruh (2015). 
world, a world that provides the context for Conde's writing - but from the perspective of the West, where liberal democracy was the only model left. ${ }^{15}$ Fukuyama's "the end of history" reflects on the growing importance of "the body, its needs, and fears" when, after the Cold War is over, "men are unable to affirm that any particular way of life is superior to another" (Fukuyama 1992: 305). Fukuyama would see this attention to food as a symptom of a decline in values related to the decline of moral debate and critical citizenship. But there is a fair amount of irony in the context of Cuba's late socialism, which consists of a capitalism simultaneously repressed and ubiquitous to sustain a repressive political stasis. ${ }^{16}$ I suggest that Padura's novels, which are read in many languages and have received many international awards, are popular in part because they present another route to the very same point where Fukuyama ends up, in which simple pleasures are the go-to response to political disaffection. ${ }^{17}$

\section{Mayra Montero's darkness}

Cuban-Puerto Rican Mayra Montero’s novel Tú, la oscuridad (1995) has been labeled the first explicitly environmental novel in the Caribbean. ${ }^{18}$ Its cosmopolitan moment is what Bill McKibben has called "The End of Nature": "that moment when for the first time human beings had become so large that they altered everything around us. That we had ended nature as an independent force, that our appetites and habits and desires could now be read in every cubic meter of air, in every increment on the thermometer"19 (McKibben 2003: xiii).

The novel follows the extinction of a subspecies of frog in Haiti in the 1990s. Critics understand that the protection of animals often appears in competition with human welfare in a situation of persistent poverty and political violence. Indeed, there is a structural continuity between ill treatment of animals for the well-being of humans, and of other humans that are marked as

15 For a discussion of how Fukuyama himself was misread, see Fukuyama (2010).

16 Ariana Hernández-Reguant coined the term "late Socialism" to describe the period in Revolutionary Cuba after the fall of the Berlin Wall when the government adopts capitalist measures to ensure the survival of the socialist Revolution.

17 For a reading of Nietzsche's ideas in relation to the Cuban Revolution, see Community and Culture in Post-Soviet Cuba (De Ferrari 2014). In this book, I read novels by Padura, Jesús Díaz and Abel Prieto as incapable of breaking apart from the revolutionary ethos, in opposition to "perverse" and "evil" texts whose Nietzschean suspicion of (revolutionary, manly) virtues allows them to break away from the complicit social contract.

18 See Paravisini-Gebert (2014: 350). See also Heise (2016: 167).

19 In the prologue to the revised version. 
animalistic (Heise 2016: 167). This is why the novel stages the act of "reading" ethnographically as well as ecocritically. It is in this double approach that the novel somewhat approximates what it looks like to read not only global "appetites and habits and desires", but also local impotence and fear "in every cubic meter of air" - to paraphrase McKibben (2003).

The protagonist, an American herpetologist named Victor Grigg, travels to Haiti in the 1990s with the mission of finding a near-extinct frog, the Eleutherodactylus sanguineus, commonly known as a grenouille du sang because of its color. The disappearance of the grenouille $d u$ sang takes place among similar disappearances of similar frogs around the world. These disappearances are accounted for in the form of short scientific interchapters, while the main chapters are narrated alternately by either Grigg and Thierry Adrien, his local guide, as they tell each other their life stories. Each monologue acts as a first-person narration - an oral "book" that is interpreted and appropriated read - by the other. This dynamic is more explicitly played out in the chapter "Alma de macoute" ['Like a Macoute'] that presents Grigg's thoughts while he listens to Adrien's stories. Adrien talks about the infidelities of a promiscuous woman called Ganesha, the lover of Grigg's herpetologist predecessor Papa Crapaud, which prompts Grigg to reflect on his own marital problems. The novel's dual structure showcasing the life stories of the American scientist and the Haitian guide advances the importance of narrative in claiming human status. At the same time, the power imbalance between the two protagonists recreates an ethnographic exchange to the point that Grigg, who notices that Adrien sometimes includes information about the frog when he talks about his life, starts recording him (Montero 1995: 35). Adrien, the native informant, functions as the open book that Grigg reads and rereads in his double efforts to explain Haiti and his own life to himself.

The novel explores the value of different lives at the end, when the overcrowded ferry taking the two men out of the dangers of Jérémie to Port-auPrince sinks, killing two thousand Haitians, along with Grigg, Adrien, and the last specimen of the grenouille $d u$ sang. The fact that the death of thousands of people - poor, anonymous Haitians - seem to matter less than the disappearance of the frog in the novel shows the dehumanizing capacity of poverty, which, as Judith Butler suggests, makes some lives more grievable than others. The end, however, does not resolve the ambiguous place that Grigg and Adrien occupy in a compromised hierarchy. Neither valuable frog nor devalued - generic - "Haitian", the two men have eluded the label "specimen" to attain protagonist status.

Nevertheless, the blurry line separating human and nonhuman animals in this context is further complicated by the fact that humans are cast as members 
of recognizable "types". At the beginning of the story, we seem to have one of each, Thierry, Grigg, the elusive frog, which, once found, is scientifically described as the male specimen of a near extinct subspecies. Similarly, before helping Grigg, Thierry had served as guide for Jasper Wilbur, another herpetologist whom he called Papa Crapaud. Foreign scientists belong to the enlightened side of the colonial enterprise. The scientist category acquires new members as Grigg intersects two botanists from the New York Botanical Garden who are looking for a rare female specimen of a near extinct subspecies of a cactus in the same area. The botanists have a guide called Paul. Thierry Adrien, who has been a guide for several decades, shares both name and wife with his (late) father, suggesting repetition. He is one in a string of brothers several “Adriens". Women also appear as specimens within subcategories. Local women, foreign women, unfaithful women, and crazy women all seem to follow recognizable patterns through repetition and some degree of substitutability. Women and native guides, but also scientists and father figures, make humans and their stories appear interchangeable and capable of endless reproduction.

In the context of a story built on the obsession with species and specimens, men and women cease to be individuals and become types with recognizable behavior within predictable ecosystems. Therefore, phrases such as to be like a macoute, to behave like a macoute, to be a man in a string of men who love and abandon women or are deceived by them strips the characters of their individuality. A more complex parallelism involves their fears and desires. On the one hand, Adrien's fear of the grenouille, (he believes the frog is a bad omen) is the negative side of Grigg's desire to find it; on the other, Adrien has a growing desire to see the ostriches in Grigg's father's farm and bring one to Haiti, where it would be the first of its kind, while Grigg is actually afraid of his inheritance. Thanks to vaudou ideas, repetition may occur even in death since, according to Adrien, "a man walks the same roads again and again without knowing, believing that they are new". ${ }^{20}$ Adding, more ominously, "The dead also walk the same roads again and again" (Montero 1995: 238-239).

The novel recreates an atmosphere in which science is incapable of grasping the real story of animal extinction and, implicitly, of human violence. The scientific interchapters are brief, descriptive, and attest to the limitations of the scientific method with phrases like "inexplicable deaths" (Montero 1995: 71); “the mystery was never resolved” (1995: 71); “unknown causes” (1995: 21);

20 Originally, "Un hombre repite todos sus caminos, los repite sin darse cuenta y se hace la ilusión de que son nuevos" and, "Los muertos también repiten sus caminos". 
"fruitless search" (1995: 161). By contrast, Dr. Emile Boukaka, a Haitian surgeon who combines scientific methods with vaudou beliefs, suggests that the cause of the disappearance of the frogs is not "acid rain, herbicides, deforestation" as scientists claim (1995: 132), but rather it is due to Agwé Taroyo, "the god of the waters", who has summoned the frogs to stay deep in the water (1995: 131). Ursula Heise sees the appeal to the supernatural as "one of the weakness of the novel", since it helps "block any detailed social and political analysis" (Heise 2016: 171). And, what is more, "it also seems to exonerate humans from any responsibility in the ongoing extinctions" (Heise 2016: 172).

And yet, a useful theory transpires in an implicit analogy between scientific discourse and social analysis. Namely, the novel observes that "the younger frogs get disoriented and expose themselves to dangerous situations because they lack malice; the capacity for self-protection is a learned behavior for most amphibians"21 (Montero 1995: 225; my emphasis). This observation suggests that the political problems in Haiti are attributable to the lack of social options and a moral compass. An environment of violence is the consequence of a modernity that excludes young Haitians - as well as the frogs. Perhaps disorientation is the result of dependency on a "weak" social cosmology in which responsibility is often delegated to fate, as well as the generalized corruption that makes accountability impossible. Although it would be fair to say that even Grigg, the scientist, accepts the role of fate when a suffering Adrien complains that "a man never understands when the sadness that will accompany him for the rest of his life begins". To which Grigg replies "Neither sadness nor happiness [...] A man never knows anything, Thierry. That is his tragedy" (Montero 1995: 133).

As Liza Paravisini-Gebert suggests, it is the entire nation, not just the frog, that is in danger of extinction (2014: 351). Grigg, who is miserably ignorant at first, understands this after climbing a steep learning curve. He finds that he no longer can report back to Vaughan Patterson, the scientist who sent him to look for this frog. Grigg has not only learned to read Haiti not only in the generic terms known to any outsider, but also understands its metarules as a country in which everyone is at risk of peril: "How to explain to Patterson that Haiti, oh God, was dying out, and that pile of bones growing in front of our eyes [. . . is the only thing that will remain"22 (Montero 1995: 226-227). At first,

21 Originally, "Se desorientan o se pierden las ranas más jóvenes; se exponen a condiciones peligrosas porque no tienen malicia. La capacidad de protegerse y de ocultarse es una conducta aprendida en casi todos los anfibios”.

22 Originally, “¿Cómo meterle en la cabeza [a Patterson] que Haití, gran dios, se estaba terminando, y que esa loma de huesos que iba creciendo frente a nuestros ojos [.. .] era todo lo que iba a quedar?”. 
Grigg functions as Patterson's eyes in Haiti. However, when Grigg learns the "habits" of the land, he suffers the same as the "good" readers I have discussed above. Too much understanding clouds legibility.

The darkness in the novel's title is about the anticipation of a catastrophe. While the title of the novel Tú, la oscuridad, refers to an oracle-style incantation that announces impending death and helps embrace it without fear (Montero 1995: 239), the translation In the Palm of Darkness seeks to establish a submarine connection with Polish-English writer Joseph Conrad's novel Heart of Darkness. It is true that there are echoes between the two, but they are quite subtle and perhaps even irrelevant. The parallelism is probably an editorial strategy to invite foreign readers into the unknown by invoking the association with a familiar writer, making visible the hidden threads that weave travel, whiteness, and self-knowledge. However, the English title grants the novel membership in a group of cosmopolitan novels about the dark art of losing one self in nature, or because of it. It is no coincidence that genre and genus are etymologically related: similarity and substitutability, structural aspects of literary artifacts, are also the mark of the species.

\section{Readers without habits}

I have reflected here on how reading in Caribbean literature can help us understand World Literature otherwise. I have argued that reading the other usually functions to the extent that the reader accepts that creative knowledge sometimes requires forgoing the specificities of the other. This I have called reading at the level of species. I am aware that the phrase sounds dangerous. In fact, I could as easily have written an essay against "reading at the level of the species”, defending historical details and geographic minutia from overreaching World Literature critics and Latin Americanists. After all, what is Latin American literature if not an artificial concept that nonetheless orients our teaching assignments, our conferences, and our library holdings. My point here is that what Caribbean - as opposed to Latin American - literature shows is that occupying our historical time together across cultures is ultimately worth the risk. It is true that the role of the discipline that we call World Literature is to remain humbly vigilant about what is gained and what is lost when reading across cultures. But it is also true that imperfect reading can be a more liberating form of thinking (with) the other. In my analysis of El siglo de las luces, I borrowed from Žižek the notion that revolutionaries are "figures without habits" (Žižek 2007). The true revolutionary ignores the metarules - the implicit understanding of how to play the social game - to make new discoveries. 
I want to conclude this reflection by suggesting that the Caribbean contribution to World Literature is, precisely, to appreciate revolutionary readers; for, historically, Caribbean readers are readers without habits.

\section{Works cited}

Aching, Gerard (2012): “El 'derecho a la opacidad' y la literatura mundial”. In: De Ferrari,

Guillermina (ed.): Special Issue of 1616: Anuario de Literatura Comparada, 2, pp. 33-47.

Beck, Ulrich (2009): World at Risk. Trans. Ciaran Cronin. Cambridge: Polity.

Buck-Morss, Susan (2009): Hegel, Haiti and Universal History. Pittsburgh: Pittsburgh

University Press.

Butler, Judith (2016): Frames of War: When is Life Grievable? London/New York: Verso.

Carpentier, Alejo (2001): El siglo de las luces. Barcelona: Seix Barral.

De Ferrari, Guillermina (2014): Community and Culture in Post-Soviet Cuba. London/New York:

Routledge.

De Ferrari, Guillermina (2012): "Utopías críticas: La Literatura Mundial según América Latina". In: De Ferrari, Guillermina (ed.): Special Issue of 1616: Anuario de Literatura Comparada, 2, pp. 15-32.

De Ferrari, Guillermina (2005): “Las palabras y las cosas: El lenguaje de la revolución en El siglo de las luces de Alejo Carpentier y Los palacios distantes de Abilio Estévez”. In: Rodríguez, Alexis Márquez (ed.): Alejo Carpentier ante la crítica. Caracas: Monte Ávila Editores, pp. 307-350.

De Ferrari, Guillermina/Unruh, Vicky (2015): “Padura después del vendaval”. In:

A Contracorriente, 13, 1 (Fall 2015), pp. 1-12.

Fischer, Sibylle (2004): Modernity Disavowed: Haiti and the Cultures of Slavery in the Age of Revolution. Durham/London: Duke University Press.

Fukuyama, Francis (2010): “'The End of History’ 20 Years Later”. In: New Perspectives Quarterly, 27, 1, pp. 7-10.

Fukuyama, Francis (1992): The End of History and the Last Man. New York: The Free Press.

Gates, Henry Louis (1988): “James Gronniosaw and the Trope of the Talking Book". In: Olney, James (ed.): Studies in Autobiography. Oxford: Oxford University Press, pp. 51-72.

Gilroy, Paul (1993): The Black Atlantic: Modernity and Double Consciousness. Cambridge, MA: Harvard University Press.

Glissant, Édouard (1997): Poetics of Relation. Trans. Betsy Wing. Ann Arbor: Michigan University Press.

Heise, Ursula (2016): Imagining Extinction: The Cultural Meanings of Endangered Species.

Chicago/London: Chicago University Press.

Hernández-Reguant, Ariana (2009): “Writing the Special Period: An Introduction”. In:

Hernández-Reguant, Ariana (ed.): Cuba in the Special Period: Culture and Ideology in the 1990s. New York: Palgrave MacMillan, pp. 1-18.

James, Marlon (2009): The Book of Night Women. Oxford: Oneworld Press.

McKibben, Bill (2003): The End of Nature: Humanity, Climate Change and the Natural World. London: Bloomsbury Publishing.

Montero, Mayra (1995): Tú, la oscuridad. Barcelona: Tusquets. 
Padura, Leonardo (2013): Herejes. Barcelona: Tusquets.

Padura, Leonardo (2005): La neblina del ayer. Barcelona: Tusquets.

Paravisini-Gebert, Lizabeth (2014): "Extinctions: Chronicles of Vanishing Fauna in the Colonial and Postcolonial Caribbean". In: Garrard, Greg (ed.): The Oxford Handbook of Ecocriticism. Oxford: Oxford University Press, pp. 341-360.

Sarduy, Severo (1972): “El barroco y el neobarroco”. In: Fernández Moreno, César (ed.): América Latina en su literatura. Mexico: Siglo XXI.

Siskind, Mariano (2014): Cosmopolitan Desires: Global Modernity and World Literature in Latin America. Chicago: Northwestern University Press.

Unruh, Vicky (2015): “Heretics, Heritage, Possession: Leonardo Padura's Herejes”. In: A Contra corriente, 13, 1 (Fall 2015), pp. 128-149.

Žižek, Slavoj (2007): Robespierre: Virtue and Terror. Trans. John Howe. London/New York: Verso. 